\title{
Forestland owners' willingness to consider multiple ways of supplying biomass simultaneously: implications for biofuel incentive policies
}

\author{
Bernabas Wolde* \\ Department of Earth and Environmental Studies, Montclair State University, Montclair New \\ Jersey, 07043, Voice: +17033475582, woldeb@ montclair.edu \\ *Corresponding Author \\ Pankaj Lal \\ Department of Earth and Environmental Studies, Montclair State University, Montclair New \\ Jersey, 07043, lalp@montclair.edu \\ Pralhad Burli \\ Department of Earth and Environmental Studies, Montclair State University, Montclair New \\ Jersey, 07043. burlip1@montclair.edu
}

\begin{abstract}
Because socioeconomic based approaches account for relevant limiting and motivating factors, they provide a more realistic measurement of forestland owners' willingness to supply biomass for bioenergy production- information useful to policy makers in setting production targets and in designing relevant incentive programs. Although forestland owners can supply biomass using different means, including supplying biomass from existing stands and changing land use to establish feedstock plantation, among others, previous studies mostly focus only on a given way of supplying biomass at a time. This produces incomplete information that adversely affects its use. By presenting survey takers in Virginia and Texas three different ways of supplying biomass at the same time, we determine forestland owners' willingness to consider multiple ways of supplying biomass simultaneously and identify the factors that predict such behavior, assess overlap in forestland owners across the different ways of supplying biomass, and assess if and how respondents' forest management plans and sustainability concerns correspond with their supply decision. Our results show a higher and more articulated rate of willingness to supply biomass than reported in previous studies. The results also suggest that opportunities exist for synergizing programs that incentivize disparate ways of supplying biomass.
\end{abstract}

Keywords: woody bioenergy, feedstock supply, incentive programs, energy supply chain, forestland owners 


\section{Introduction}

Estimating the amount of biomass available for bioenergy production is important both at the policy making and at the refinery level (Aguilar et al. 2014). Policy makers use such information to develop feasible production targets and corresponding incentive programs. At the refinery level, decision makers use such information to determine the scale of conversion facilities, select facility site, and other logistics. Given an existing demand for and supply of forest products, such information can also be used in assessing the potential competition between the traditional forest based industry and the emerging woody bioenergy industry (Galik et al. 2009). Given an amount of residual biomass required to maintain soil nutrient, the scale and original use of the land converted to establishing feedstock plantation, and other considerations, one can also estimate the environmental impacts associated with a growing woody bioenergy industry.

Although the energy independence and security act of 2007 set a 16 billion gallons yearly production target for cellulosic ethanol by 2022, aiming to create a large and rapidly growing biofuels production capacity for transportation use by guaranteeing a market, uncertainty exists regarding forestland owners' willing to supply the large and continuous flow of the biomass required (Congressional Research Services [CRS], 2011). Since federal land is ineligible, the biomass supply is anticipated to come from forests on privately owned lands, most of which is located in the southern US. However, a functional market, by way of a structured system where biomass suppliers and commercial scale conversion facilities make deals, does not exist yet, making the forestland owners reluctant to devote land and other resources to producing biomass, some of which can take years before a full harvest capacity is reached. Thus, whether and how specifically private forestland owners will choose to supply biomass and what it 
would take to incentivize this choice are not fully known, posing a challenge to our ability to ensure a constant and large supply of biomass required to meet the production target. Biophysical approaches for measuring the availability of biomass do not typically account for relevant factors such as the forestland owner's willingness to supply the biomass, instead estimating the physical availability of biomass (Becket et al., 2010; Butler et al., 2010). Because they account for relevant factors affecting forestland owners' decisions to participate in the energy supply chain, socioeconomic based approaches produce more realistic estimates of the number of forestland owners who are willing to supply biomass, the amount of biomass they will supply, and the amount of bioenergy that can be produced from their supply decision. Approaches based on socioeconomic analysis also provide insight into woody bioenergy's social acceptability, forestland owners' motivations for supplying biomass for bioenergy production, and their concerns about doing so (Butler et al. 2010; Markowski-Lindsey et al. 2012). Given that private forestland owners manage up to $70 \%$ of the forest in the southern US, a region known as the world's wood basket, learning if and why they make management decisions is important for understanding the prospects of different forest and forest related goods, services, and the policies used to affect them, including woody bioenergy (Gruchy et al., 2012; G.C. and Mehmood, 2010).

Towards these ends, forestland owners' choices are framed in terms of whether they will supply land for establishing bioenergy feedstock plantation, supply biomass from existing stand, or change management practice in ways that favorably alter the timing and yield of biomass, such as fertilization (Paula et al., 2011; Wolde et al. 2016a; Gruchy et al., 2012; Joshi et al., 2011). Rarely, however, are multiple options presented simultaneously. Whereas the surveys used by previous studies on the topic may have included references to multiple ways of 
supplying biomass and the respondents kept such options in mind while responding to the survey questions, forestland owners' biomass supply choice has not formally been modeled in the manner it is done in the current study. The selective focus on a single or a subset of the different ways forestland owners can use to supply biomass produces incomplete information that affects its usefulness in the decision and policy making processes, in turn limiting the policy's ability to affect forestland owners' behavior.

While some forestland owners may not be willing to supply biomass by establishing a feedstock plantation, for instance, they may be willing to supply biomass from their existing stand. Yet, others may be willing to consider both options simultaneously, representing a different level of willingness to supply biomass for bioenergy production. Using a selective approach also does not tell us if forestland owners who are willing to consider a given way of supplying biomass are more/less likely than others to consider other ways of supplying biomass, and which combination, among the different ways of supplying biomass, is preferred more by forestland owners than others.

We also do not know if the factors that significantly predict forestland owners' willingness to consider individual ways of supplying biomass also significantly predicts their willingness to consider multiple ways of supplying biomass simultaneously, affecting the relevance and implication of such studies to our understanding of forestland owners' broader response to woody bioenergy, the scale befitting bioenergy policies.

The different ways of supplying biomass and the corresponding economic, social, and environmental outcomes also interact with each other in complex ways and do not remain discrete. Because the positive and the negative outcomes will have a mutually reinforcing or 
mediating effect on each other, the outcomes will be different from the sum of their parts. Thus, taking the discrete approach, whereas it simplifies analysis, can be too simplistic and incomplete as it cannot account for such interactions. Determining the combination of ways forestland owners prefer, however, can be used to anticipate and plan for the potential social, economic, and environmental outcomes. This is important because understanding the outcomes associated with the way we produce and use energy allows us to learn how much negative externality is being created, to make informed choice by comparing benefits against costs, and to design policies and management plans that can internalize the said externalities. Arguably, this increases our chances of achieving the desired objectives and avoiding or minimizing unintended outcomes. Thus, whatever interests, including energy, social, economic, and environmental, to do with bioenergy production make the existing public policies necessary, where discrete ways of supplying biomass are considered, still apply when a more comprehensive approach is used, if not more so as several energy and environmental interests and policy objective are implicated, some in ways we have not considered before.

Although the sustainability of harvesting biomass for bioenergy production is an area of active research (Vance et al., 2014; Neary et al., 2002), little is known if forestland owners have sustainability concerns about woody bioenergy and how those concerns correspond with their decision to participate in the energy supply chain. Little is also known about the association between other forest management plans forestland owners have and their decision to supply biomass, information that could provide context to their decision, highlight their extension needs, and give insight into their likely response to different types of incentive programs that may be considered in encouraging supply of biomass for bioenergy production (Wolde et al. 2016b). 
Other than helping to address the issues stated above, using a framework that accounts for multiple options simultaneously provides for a better estimate of not only the quantity but also the timing of feedstock availability for bioenergy production, as the different ways of supplying biomass have different gestation periods. Combined with the percentage of forestland owners expressing preference for the different ways of supplying biomass and the set of variables that significantly predict such preference, this approach provides a more articulated information. Having such information helps us determine if the biomass supply will come from a given group of forestland owners willing to consider multiple ways of supplying biomass simultaneously or if it will come from different groups of forestland owners with each group willing to consider a single way of supplying biomass. This information is invaluable in determining how the benefits and costs associated with supplying biomass will be distributed among forestland owners.

Whereas we do not assess the structural relationship between the social, economic, and environmental outcomes that associate with the different modes of supplying biomass simultaneously, we accomplish three objectives in this paper. First, we assess the number of ways forestland owners will consider simultaneously in supplying biomass for bioenergy production, while also assessing the overlap in forestland owners across the different ways of supplying biomass. Second, we assess the socioeconomic attributes, forestland features, and motivating factors that significantly predict the number of ways forestland owners will consider simultaneously. Third, we assess if and how respondents' forest management plans and sustainability concerns correspond with the number of ways they will consider in supplying biomass simultaneously. 
The rest of the paper is organized into three sections. Section 2 presents the way we designed and administered the survey along with the statistical methods we used to analyze the data. Section 3 presents the results and discussions. Section 4 presents the conclusions drawn from the results and their implications for energy policy.

\section{Data and Methods}

\subsection{Study Area}

The study states are Virginia and Texas. The two states are from the southern US. This region is important for woody bioenergy production because it has among the world's most productive forests and up to two thirds of it is owned by private forestland owners, relevant for woody bioenergy as it is the ownership type eligible for existing incentive programs. The two states differ from each other in respects that are known to affect the decisions forestland owners make, including the average forest acreage and socioeconomic profiles, additional details provided in section 3.1 (Koontz 2001; Paula et al. 2011; Arano and Munn 2006). They also differ from each other in terms of their natural conditions, current and projected bioenergy penetration rate in the energy sector (Sample, et al., 2010; Ethanol Producers Association 2015). Thus, the two states represent diverse background settings while sharing features important for woody bioenergy. This allows us to be better able to ensure the relevance of the results to a broader range of forestland owners.

\subsection{Data collection}

We used a series of focus group discussions, pilot surveys, and peer review by extension professionals in the two study states to improve the survey's relevance and quality before sending it out to the survey participants. Using a random number generator, we selected 1800 
potential respondents with at least 20 acres of forestland from Virginia and Texas. While the use of the random number generator ensures an unbiased selection of forestland owners, the 20 acre cut off point was used to select forestland owners having an economically viable biomass production (Joshi et al. 2011). The survey asked forestland owners if they are willing to consider changing their forest management practices in response of woody bioenergy,

allocating land for establishing feedstock plantation, and supplying biomass from their existing stand. The survey also elicited demographic and forestland features, planed forest management activities, sustainability concerns, and motivating factors associated with supplying biomass. We sent survey participants the first survey, a postcard reminder, and a final reminder, following the Dillman approach (Dillman et al. 2009). With 390 responses, we had a $21.6 \%$ response rate, the 229 most complete responses being used for this study.

\subsection{Ordinal logistic model}

Given that some forestland owners are willing to consider more number of ways for supplying biomass than others, the ordinal logistic model was used to determine which socioeconomic factors, forestland attributes, and motivating factors predict their preference. As opposed to the actual distance, the model uses the order between the number of ways forestland owns will consider in supplying biomass simultaneously, iteratively fitting a succession of parallel logistic curves to the cumulative probabilities while maintaining the same parameters and different intercepts (Greene 2003). Compared to the nominal and multinomial logit models, this model does not lead to loss of important information and parsimony associated with dichotomizing the data.

The respective curves for this model can be specified as: 
$\mathrm{P}(y \leq \mathrm{k})=F(\alpha \mathrm{k}+\mathrm{X} \beta)$ for $k=1, \ldots, r-1$

$\mathrm{F}(\mathrm{x})=\frac{1}{1+\exp ^{-x}}=\exp ^{x} /\left(1+\exp ^{x}\right)$

where $r$ is the number of ways forestland owners can consider in supplying biomass and $F(x)$ is the standard logistic cumulative distribution function. The exponential of the respective coefficients gives the proportional odds ratio. Instead of imposing the number and structure of explanatory variables on the data, we used a stepwise regression approach. For predefined maximum and minimum entry and exit $p$ value thresholds, this approach iteratively selects the variables and their respective structure in determining the regression equation best fitting the data (Proust 2013).

\subsection{Cochran Armitage trend test}

Planned forest management activities such as intention to partially cut stand in the next five years were framed as binary options in the survey. Given this set up, we use the Cochran Armitage trend test to assess if the distribution of respondents who have plans to partially cut the stand relative to forestland owners who do not plan to partially cut the stand, for instance, has a statistically significant trend across the range of options in which forestland owners could supply biomass for bioenergy production (Agresti 2009).

Given a correlation coefficient, $r$, the test statistics $T^{2}$ specified as $T^{2}=(n-1) r^{2}----------------------------------(3)$

has a chi-squared distribution with 1 degree of freedom (Agresti, 2009). A $p$ value less than 0.1 suggest a statistically significant trend at least at the $90 \%$ confidence level.

\subsection{Odds ratio}


We use the odds ratio to quantify and test the statistical significance of how likely forestland owners who say 'yes' to a given way of supplying biomass will also say 'yes' to another way of supplying biomass as compared to forestland owners who said 'no' to the first option.

In a $2 * 2$ contingency table setting, the odds ratio can be specified as:

Odds Ratio $=P_{11} * P_{22} / P_{12} * P_{21}--------------------------(4)$ where $\mathrm{Pij}$ is the count of 'yes'/'no' response to the given ways of supplying biomass for bioenergy production. Estimates that contain 1 in the confidence interval are not statistically significant.

\subsection{Measure of association, Gamma}

We estimate gamma coefficients to determine the magnitude and statistical significance of the association between the number of ways forestland owners will consider in supplying biomass and the forestland owners' sustainability concerns. While the sign of the coefficients show the direction of relationship, and the $\mathrm{p}$ value the statistical significance, the coefficients themselves show the strength of the association (Agresti 2009). Given concordant pairs, Nc, and discordant pairs, $\mathrm{Nd}$, the gamma coefficient can be specified as:

$$
\mathrm{Gamma}=N_{c}-N_{d} / N_{c}+N_{d}------------------------(5)
$$

Estimates that contain 0 in the confidence interval are statistically insignificant.

\section{Results}

\subsection{Descriptive data}


Despite the slightly higher average forestland size for our survey respondents, resulting from the cutoff point used to identify survey participants, a comparison of our data with the national woodland owners' survey data for Virginia and Texas reveals reasonable comparability. Adjusting for the cutoff point, while $84.3 \%$ of Texas' and $83.15 \%$ of Virginia's forestland owners are male, the values for our data are $82.1 \%$ and $78 \%$, respectively. While $55 \%$ of Texas' and $61.2 \%$ for Virginia's forestland owners have their primary residence on the forested property, the values for our data are $43.7 \%$ and $55.8 \%$, respectively. While $92.5 \%$ of Texas' and $91.4 \%$ of Virginia's forestland owners are white, the values for our data are $89.1 \%$ and 94.8\%, respectively. The t-test we ran to determine differences between early and late respondents did not yield a significant result.

\subsection{Forestland owners' willingness to consider multiple ways of supplying biomass for bioenergy}

With the exception of $16.29 \%$ of the respondents, the rest are willing to participate in the energy supply chain by using at least one way of supplying biomass for bioenergy production. This puts the biomass supply chain participation rate at $83.71 \%$, which is higher than the

results reported in previous studies (Markowski-Lindsay et al., 2012; Becker et al., 2010; Paula et al., 2011). Methodological and geographic differences also exist between the current study and the previous studies.

\section{[Insert table 1 here]}

$25.0 \%$ of the respondents said 'yes' at least to one of the three ways in which they could supply biomass while $31.97 \%$ of the respondents said 'yes' to all three options, showing that even if some forestland owners are not interested in supplying biomass in a given way, they are 
willing to do so using other means. These results also show that forestland owners are indeed willing to consider multiple ways of supplying biomass simultaneously, justifying the need to use a more comprehensive list of options in determining forestland owners' willingness to supply biomass and in studying the implications of their decision to do so.

The odds ratio values show that forestland owners who are willing to supply biomass from their existing stand are statistically more likely to allocate land for establishing a feedstock plantation than forestland owners who are not willing to supply biomass from their existing stand, with a 2.91 odds ratio. Given the number of forestland owners who will allocate land for establishing feedstock plantation without supplying biomass from existing stand, this odds ratio figure shows, in ratio terms, the number of forestland owners who will allocate land for establishing a feedstock plantation even as they supply biomass from existing stand. Thus, for every forestland owner who is willing to allocate land for establishing a feedstock plantation without supplying biomass from existing stand, approximately 3 forestland owners (approximated from 2.91), will establish a feedstock plantation and still supply biomass from their existing stand. Similarly, such forestland owners are also willing to consider changing their silviculture practices in response to woody bioenergy, with an even higher odds ratio of 8.77, compared to forestland owners who are not willing to supply biomass from their stand. Forestland owners who are willing to allocate land for establishing feedstock plantation are also willing to consider changing their silviculture practices in response to woody bioenergy compared to forestland owners who are not willing to allocate land for feedstock plantation, with an odds ratio of 5.74 .

\section{[Insert table 2 here]}


Higher odds ratio values indicate greater overlap in respondents across the different ways of supplying biomass. Accordingly, high overlap exists between supplying biomass from existing stands and changing silviculture practice in response to woody bioenergy. This is followed by the overlap between allocating land for establishing feedstock plantation and changing silviculture practices in response to woody bioenergy. For a given amount of biomass supply

per a supply means, the high overlap suggests that the an equally high proportion of the feedstock will come from a group of forestland owners who will use multiple means of supplying biomass simultaneously instead of coming from different groups of forestland owners with each group considering single means of supplying biomass. The economic and environmental outcomes, positive and negative, associated with supplying biomass, thus, may be distributed in the same manner.

\subsection{Factors predicting forestland owners' willingness to consider multiple ways of supplying biomass simultaneously}

Two different types of motivating factors, namely, price offer and interest in enhancing scenery and hunting opportunity predict whether forestland owners will consider multiple ways of supplying biomass simultaneously, suggesting that woody bioenergy has a wide appeal and that forestland owners are willing to participate in the energy supply chain for various reasons. The higher the importance forestland owners attach to these motivating factors in making biomass supply decisions, the more likely they will consider multiple ways of supplying biomass simultaneously.

Changing forest management practices such as choosing to thin stand and remove residual biomass after timber harvest can increase aesthetics and accessibility for hunting purposes, 
while planting currently non-forested areas with feedstock such as short rotation tree species increases scenery and creates habitat for wildlife to be hunted, helping to explain why forestland owners who are highly motivated by improving scenery and hunting opportunity are willing to consider multiple ways of supplying biomass simultaneously. Although the effects of price offer both on forestland owners' willingness to supply biomass and the amount of biomass they are willing to supply has been reported (Paula 2010; Markowski et al. 2012; Becker et al. 2010), the relevance of a second, non-market oriented, factor motivating similar outcome is seldom reported and has important implications. It suggests that even in market conditions that are not enticing to profit motivated forestland owners, biomass may still be available for bioenergy production as forestland owners motivated by improving scenery and hunting opportunity participate in the energy supply chain. It is also a promising prospect for woody bioenergy as improving scenery is becoming a more popular reason why forestland owners manage forests (Straka 2011).

The survey provided basic information about woody bioenergy and the different ways in which they could supply biomass, marking the first time some of the respondents heard about woody bioenergy. Forestland owners who heard about woody bioenergy for the first time through the survey showed statistically higher willingness to consider more number of ways for supplying biomass simultaneously. On the other hand, forestland owners who said they knew about woody bioenergy before the survey are willing to consider statistically fewer number of ways for supplying biomass simultaneously. Although the survey did not elicit the content and accuracy of their knowledge about woody bioenergy as to determine why having prior information associates with willingness to consider fewer ways of supplying biomass, we anticipate that it is an unfavorable perception based on how it is affecting their decision. 
Monroe et al. (2011) reported that more than half of their survey respondents in the southern US were "not at all knowledgeable" either about the production of electricity from woody biomass or about how woody bioenergy compares to fossil fuel in terms of mitigating air pollution and greenhouse gas emission. They note that the lack and/or inaccuracy of information about different opportunities available to forestland owners can lead to missed opportunities and exacerbate suboptimal social, economic, and environmental outcomes, suggesting that a wide spread lack of information or misinformation exists (Monroe et al., 2008; Jacobson et al., 2006). This shows how educational opportunities, such as the type accomplished by the cheat talk version of the survey, can begin to address existing misperceptions, allowing forestland owners to understand and begin to explore the opportunity presented to them. The results suggest that it may be possible to increase forestland owners' willingness to consider multiple ways of supplying biomass simultaneously and that information dissemination, an inexpensive tool, may be a viable option for doing so. Given that $22.64 \%$ of the respondents had not heard about woody bioenergy before the survey, substantial opportunity exists for teaching forestland owners about the different benefits woody bioenergy offers and to correct misperception among those with prior information about woody bioenergy.

\section{[Insert table 3 here]}

Compared to older forestland owners, younger forestland owners are more willing to consider multiple ways of supplying biomass simultaneously, with a proportional odds ratio of 0.65. Poudyal and Hodges (2009) found that older forestland owners are less likely to show interest in an active forest management in general and Joshi and Mehmood (2011) found evidence to suggest that older landowners were less willing to supply woody biomass. Besides the supply 
of biomass, Shivan and Mehmood (2010) note that forestland owners' age can affect their policy preference for bioenergy, finding that older forestland owners supported federal and state cost-share programs.

Level of income also significantly predicts forestland owners' willingness to consider multiple ways of supplying biomass simultaneously. Those who make more than $\$ 90,000$ a year are more likely to consider multiple ways of supplying biomass simultaneously than forestland owners who make less than $\$ 90,000$, who, in turn, are more likely to consider multiple ways of supplying biomass simultaneously as compared to those who make less than $\$ 22,000$.

Forestland owners with higher income are better able to take advantage of emerging market opportunities and to weather adjustments along the way. Shivan and Mehmood (2010) also note that forestland owners' income affects their policy preference, finding that higher income associates with support for tax based policies.

The variable we used to determine the forestland owner's dependence on working the land for income, however, did not produce a significant result. Because higher dependence on working the land for yearly income could reduce the forestland owners' flexibility in making the kinds of changes involved in adopting multiple ways of supplying biomass simultaneously, we had anticipated that this variable would be negative and significant. The results do not bear that out.

Having recently established stand, as approximated by the average diameter of the tree on their stand, significantly predicts if forestland owners will consider multiple ways of supplying biomass simultaneously. Compared to forestland owners with stands averaging above 14 inches in diameter, forestland owners with stand averaging less than 14 inches in diameter are more willing to consider multiple ways of supplying biomass simultaneously. While having 
recently established stand provides sufficient opportunity to decide if they want to supply the stand to woody bioenergy production and to incorporate new forest management practices that favorably alters the volume and timing of biomass in response to the new market opportunity woody bioenergy presents.

Despite the public benefits that can result from woody bioenergy such as contributing to national energy security, mitigating climate change, reducing risk of pest and wildfire outbreak in overstocked forests, these factors did not significantly predict willingness to consider multiple ways of supplying biomass simultaneously. We also do not find acreage, mode of land acquisition, absenteeism, gender, level of education, and membership in forestry/environmental association to be statistically significant in predicting the number of ways forestland owner will consider in supplying biomass.

\subsection{Sustainability concerns, planed forest management activities, and willingness to consider multiple ways of supplying biomass simultaneously}

Sustainability concerns could provide context for the forestland owners' biomass decision. Assessing forestland owners' sustainability concerns is also important in understanding whether or not they know and are concerned about the potential adverse impacts that can result from their biomass supply decisions, gives the policymaker a baseline information on the energy related environmental outcomes that may not be getting sufficient attention from the people who can affect the said outcomes, and identify potential compliance and reporting requirements. Such information may also help one determine forestland owners' extension needs and, in turn, help extension professionals develop the corresponding educational resources. Instead of the fragmented work, where the biomass supplies and the sustainability 
concerns resulting from such supplies are assessed based on responses from different group of respondents, generating such information from the same group of respondents could preferable and may our understanding of how they are interrelated.

Accordingly, we find statistically significant relationships between willingness to consider multiple ways of supplying biomass simultaneously and some of the sustainability concerns associated with doing so. The statistical significance and the negative sign of the coefficients of associations suggest that concerns about potential adverse environmental outcomes, real or perceived, help to explain forestland owners' hesitation to consider multiple ways of supplying biomass simultaneously.

\section{[Insert table 4 here]}

Forestland owners who are willing to consider fewer ways of supplying biomass simultaneously tend to report higher concern about potential adverse effects on soil and water quality, timber growth and health, and sustainable forest management in general.

Forestland owners who are reluctant to consider multiple ways of supplying biomass simultaneously are statistically similar to the other forestland owners in terms of their perception about the availability and sufficiency of BMPs. Yet, they are significantly more

likely to be concerned that the practice will have adverse effects on soil, water, timber growth and health. Future studies are required to determine why there is a disconnection between forestland owners' tendency to think that BMPs are available and that they can help maintain soil and water quality while they still think that harvesting forest biomass would still lead to low soil and water quality. The results from the previous section suggested that forestland owners with prior information about woody bioenergy are less likely to express willingness to 
consider multiple ways of supplying biomass simultaneously, suggesting that what they know about woody bioenergy, accurate or not, may be that such adverse outcomes associate with the practice, especially considering that they are no more/less likely than others to be concerned about the potential need for extra employee and equipment and the economics of supplying biomass

We also find statistically significant associations between the number of ways forestland owner will consider in supplying biomass simultaneously and their forest management plans. We find that some forest management plans, partially harvesting and clear cutting stand specifically, associate with willingness to consider multiple ways of supplying biomass simultaneously. These activities make the said decision a relatively easier adjustment as they both are activities that make woody biomass available for bioenergy, create an opportunity to regenerate land by growing feedstock for bioenergy, and allow one to manage stand with new silviculture practices. Such forestland owners also plan to develop written forest management plans, hinting at intentions of a more active forest management practice, which, coupled with the opportunity presented by clear cutting or partially cutting the stand, make supplying biomass through multiple means simultaneously a relatively easier adjustment. Paula et al. (2011) note that landowner who engaged in active land management are more likely to supply woody biomass.

\section{[Insert table 5 here]}

\section{Conclusions and policy implications}

This section synthesizes the results with the relevant background information to describe the broader benefits and opportunities that the framework presents. The results show that 
forestland owners are willing to consider multiple ways of supplying biomass simultaneously, not just one way of doing so at a time. Forestland owners that say 'yes' to a given way of supplying biomass are also more likely than others to say 'yes' to other ways of supplying biomass. The absence of programs that incentivize changes in forest management behavior in response to woody bioenergy, which is an option forestland owners are willing to consider, represents a missed opportunity. The results also have several implications for the existing biofuel incentive programs.

The current incentive programs provide financial support for discrete ways of supplying biomass. Integrating the programs, in a manner that corresponds to the way forestland owners are planning to supply biomass, could offer several benefits to the forestland owners and the implementing agency as well. For instance, harvesting only residual biomass can be inefficient for the forestland owner as it can damage standing trees, existing equipment are not designed for it, and takes more time and money per given volume of feedstock (Bolding et al. 2010; Egan et al. 2009). Harvesting residual biomass simultaneously with round timber, however, addresses the said challenges and is preferred by large-scale logging operators, and, as the results show, it is one of the forestland owners' preferred ways of supplying biomass (Bolding et al. 2010; Greene et al. 2004). Moreover, this could reduce feedstock cost for conversion facilities and allow forestland owners net revenue even when presented with low offers from loggers (Dirkswager et al. 2011; Greene et al. 2004). Under such circumstances, it may cost less to incentivize the supply of biomass for bioenergy production. The existing incentive structure, however, is not designed to take advantage of such opportunities. On the contrary, land enrolled in one program is not eligible for other programs (Congressional Research Services [CRS], 2013). Similarly, if an eligible feedstock is delivered to a conversion facility, 
the payment from enrolling the land would be reduced by $25 \%$ or on a dollar for dollar basis (CRS, 2011), penalizing such a practice, contradicting the stated objective of incentivizing biomass supply and the demonstrated interest of the forestland owners.

Integrating the incentive programs may also give forestland owners an opportunity to learn how else they can supply biomass and, if they were already considering the other options, allow them to more easily enroll under such programs. Thus, it would address the information gap, where, as shown by previous studies, eligible forestland owners can fail to take advantage of the resources available to them because they did not know of its availability (Schaaf and Broussard 2006).

The few programs that exist currently vary from one another in terms of eligibility requirement, length of the contract, payment type, and payment limits, among others (CRS 2013). Having to navigate multiple such distinct programs ran by various agencies may be challenging for some forest landowners and easier application processes may facilitate initial and continued enrollment in such incentive programs (Fortney et al. 2011; Schaaf and Broussard 2006). Thus, integrating the programs may make navigating such programs easier for eligible and interested forestland owners.

For the implementing agency, it may also reduce communication barriers among various implementing agencies, reduce duplication of effort, increase the opportunity to identify and address new and previously unmet needs. Making known such programs exist and managing contracts under one program may also reduce the cost of running such programs. Thus, it may be possible to spend less for the same level of enrollment or to enroll more eligible applicants for the same cost. This is important considering that the cost of running programs such as the BCAP has been higher than initially projected and necessitated a considerable reduction in 
eligible land cap over time, requiring offsetting reductions in budget and bringing to question the re-authorization of the program altogether (CRS, 2011).

The matching payment program, which pays up to $\$ 45$ per ton, was the first of the two programs under the Biomass Crop Assistance Program, initiated by the food conservation and energy act of 2008, to be rolled out. This program, targeting residual biomass, was based on the anticipation that it will not displace other land use types and covers, including food crops on cropland and grassland. Despite this expectation, it had the unintended consequence of driving biomass price higher and the supply away from its other uses by landscapers, manufacturing and nursery industries, and particleboard manufacturers. For this reason, the incentive program was temporarily discontinued (CRS, 2014). If the competition, for a type of biomass with limited highly valued alternative uses, is considerable enough to justify discontinuation of the incentive program, one may reasonably anticipate a more complex set of adverse competitive and environmental outcomes, not all of which are fully recognized and quantified yet, when the other biomass supply options, which involve multiple high valued alternative uses, are implemented by the forestland owners. The likelihood that the forest landowners will also change land-use and consider using chemical inputs in their forest management practices has important implications for agricultural markets, including grains, displaced land, and environmental outcomes, including the energetic balance and life cycle greenhouse gas emissions (Mayfield et al. 2007). Because we have not looked at the biomass supply options simultaneously, we have neither anticipated the potential adverse outcomes nor set up programs necessary to address the said outcomes. Thus, it is reasonable to anticipate that the programs risk running into unanticipated outcomes, posing a challenge for their continued implementation. Given that the incentive programs are partly aimed at managing uncertainty, it 
is important that the continued implementation of the incentive programs does not become uncertain itself due to previously unforeseen outcomes that could have been anticipated if one were using a more comprehensive approach.

Whereas the production of biofuels takes place during the whole year, harvesting of residual biomass takes place over a few months, implying large storage needs and alternative biomass supply means with a varying or wider harvesting time window (Ashton et al. 2007). Forestland owners' willingness to consider multiple ways of supplying biomass, not all of which face a similar harvesting time and constraint is a promising prospect for woody bioenergy (Ashton et al. 2007). This applies not only or a given year's feedstock supply, but also in the long term. While supplying residual biomass may help meet existing demand, forestland owners' willingness to consider supply options such as dedicated plantations with higher per acre feedstock supply and whose harvest time coincides with a more established industry than exists currently and requiring a higher quantity of feedstock supply, is also a promising prospect for woody bioenergy (Foster and Mayfield 2007).

The various levels of forestland owners' willingness to consider multiple ways of supplying biomass simultaneously, if at all, and the statistical significance of some variables compared to others, suggests that the relevant bioenergy incentive programs should also be multi-tiered and adapted to the predictor variables. Because such tailored measures benefit from a more comprehensive accounting of the forestland owners preference, they may be better positioned to affect forestland owners' choices. This may be done, for instance, by tailoring relevant program features, such as what the incentive programs pay for, how much they pay, and how long the contracts last, to the number of ways the forestland owner will consider simultaneously in supplying biomass and relevant socioeconomic attributes such as income. 
Forestland owners' willingness to consider multiple ways of supplying biomass simultaneously is partly motivated by the desire to improve scenery and hunting opportunity, suggesting that policies that do not primarily deal with energy production and use may indirectly affect biomass supply, and perhaps how well existing bioenergy policies themselves affect forestland owners' biomass supply decisions. Although interventions in the energy market are often justified by the need to internalize positive externality and account for the public good nature of woody bioenergy's benefits, including its ability to contribute to national energy security and reduce greenhouse emissions, these motivations do not resonate with the forestland owners significantly enough as to lead them into considering multiple ways of supplying biomass simultaneously (Greene et al. 2006).

Significant association exists between forestland owners' willingness to consider multiple ways of supplying biomass simultaneously and their planned forest management activities, suggesting that those with a more active forest management tendency, facing relatively less of an adjustment, are more willing to consider this decision. It also suggests that the reluctance of some forestland owners to consider multiple ways of supplying biomass simultaneously may not necessarily be a reflection of their judgement about woody bioenergy per se, instead signaling a relatively inactive forest management tendency in general. It also suggests that land use, and forest management policies as well as extension and outreach programs that result in a more active forest management tendency may increase forestland owners' willingness to participate in energy supply chain indirectly (Shivan and Mehmood 2010). The generic nature of the motivating factors that significantly predict willingness to consider multiple ways of supplying biomass simultaneously and the association of such decision with an active forest management tendency in general suggests that policies and outreach efforts aiming to 
encourage such decision may not necessarily have to rely on the unique attributes of woody bioenergy.

The sustainability concerns of forestland owners, despite relevant BMPs and their own assessments of BMPs' availability and sufficiency, represent opportunities to synergize energy policy and extension programs improve perceptions about woody bioenergy, and educate forestland owners on how to avoid or minimize the real and perceived, adverse effects of supplying biomass (Monroe and Oxarart 2011). However, policies aiming to boost biomass supply would have higher success by prioritizing and targeting forestland owners who do not have the said sustainability concerns and those who have plans to actively manage their stands.

Given regional differences in some respects of forest management, such as the share of forestland managed by private forestland owners, future studies are needed to adapt the results and implications of this study to other regions and states. Future studies are also needed to build upon this study and estimate the amount of biomass for bioenergy production purposes, assess the economic and environmental outcomes that will result from forestland owners' decision to consider multiple means of supplying biomass simultaneously.

\section{Acknowledgements}

Authors gratefully acknowledge support for this study from US Department of Agriculture National Institute of Food and Agriculture Grant 2012-67009-19742, partial support from the U.S. Department of Energy's Office of Energy Efficiency and Renewable Energy, Bioenergy Technologies Office and sponsored by the Energy's Office U.S. Department of Energy's

International Affairs under award number, DE-PI0000031, Montclair State University, Virginia Polytechnic and State University, and Texas A\&M AgriLife Research.

\section{References}


Agresti, A., 2007. An introduction to categorical data analysis. Hoboken. NJ: Wiley.

Aguilar, F.X., Cai, Z., D'Amato, A.W., 2014. Non-industrial private forest owner's willingnessto-harvest: How higher timber prices influence woody biomass supply. Biomass and Bioenergy $71,202-215$.

Ashton, S.; B. Jackson; R. Schroeder. 2007. Storing Woody Biomass. In: Hubbard, W.; L. Biles; C. Mayfield; S. Ashton (Eds.). 2007. Sustainable Forestry for Bioenergy and Bio-based Products: Trainers Curriculum Notebook. Athens, GA: Southern Forest Research Partnership, Inc.

Ashton, S.; B. Jackson. 2007. Small-scale Woody Biomass Harvesting Systems. In: Hubbard, W.; L. Biles; C. Mayfield; S. Ashton (Eds.). 2007. Sustainable Forestry for Bioenergy and Biobased Products: Trainers Curriculum Notebook. Athens, GA: Southern Forest Research Partnership, Inc.

Beach, R.H., Pattanayak, S.K., Yang, J.-C., Murray, B.C., Abt, R.C., 2005. Econometric studies of non-industrial private forest management: a review and synthesis. Forest Policy and Economics 7, 261-281.

Becker, D.R., Klapperich, J.J., Domke, G.M., Kilgore, M.A., D'Amato, A.W., Current, D.A., Ek, A.R., 2010. 2010 Outlook for Forest Biomass Availability in Minnesota: Physical, Environmental, Economic, and Social Availability.

Bolding, M.C., Barrett, S.M., Munsell, J.F., Groover, M.C., 2010. Characteristics of Virginia's logging businesses in a changing timber market. Forest products journal 60, 86.

Butler, B.J., Ma, Z., Kittredge, D.B., Catanzaro, P., 2010. Social versus biophysical availability of wood in the northern United States. Northern Journal of Applied Forestry 27, 151-159.

Butler, B.J., Miles, P.D., Hansen, M.H., 2012. National Woodland Owner Survey Tabler Webapplication Version 1.0. USDA Forest Service, Northern Research Station, Amherst, MA. [Available online at http://fiatools.fs.fed.us/NWOS/tablemaker.jsp]

Congressional Research Service CRS 2010. Cellulosic Ethanol: Feedstocks, Conversion Technologies, Economics, and Policy Options

Congressional Research Service CRS 2011. Biomass Crop Assistance Program (BCAP): Status and Issues

Congressional Research Service CRS 2011. Cellulosic Biofuels: Analysis of Policy Issues for Congress

Congressional Research Service CRS 2013. Alternative Fuel and Advanced Vehicle Technology Incentives: A Summary of Federal Programs.

Dillmann, D.A., Smyth, J.D., Christian, L.M., 2009. Internet, mail, and mixed-mode surveys: The tailored design method. Hoboken: Wiley. 
Dirkswager, A.L., Kilgore, M.A., Becker, D.R., Blinn, C., Ek, A., 2011. Logging business practices and perspectives on harvesting forest residues for energy: A Minnesota case study. Northern Journal of Applied Forestry 28, 41-46.

Ethanol Producers Association. Distribution of plants. 16 Dec 2015. http://www.ethanolproducer.com.

Foster, C.D. ; C. Mayfield. 2007. Bioenergy Production in Planted Pine Forests. In: Hubbard, W.; L. Biles; C. Mayfield; S. Ashton (Eds.). 2007. Sustainable Forestry for Bioenergy and Biobased Products: Trainers Curriculum Notebook. Athens, GA: Southern Forest Research Partnership, Inc.

Fox, T.R., Jokela, E.J., Allen, H.L., 2007. The development of pine plantation silviculture in the southern United States. Journal of Forestry 105, 337-347.

Galik, C.S., Abt, R., Wu, Y., 2009. Forest biomass supply in the southeastern United Statesimplications for industrial roundwood and bioenergy production. Journal of Forestry 107, 6977.

Greene, W.D., Mayo, J.H., Egan, A.F., 2004. Causes and costs of unused logging production capacity in the southern United States and Maine. Forest Products Journal 54, 29.

Greene, J.L., Bullard, S.H., Cushing, T.L., and Beauvais, T. 2006. Effect of the federal estate tax on nonindustrial private forest holdings. J. For. 104(1): 15-20.

Gruchy, S.R., Grebner, D.L., Munn, I.A., Joshi, O., Hussain, A., 2012. An assessment of nonindustrial private forest landowner willingness to harvest woody biomass in support of bioenergy production in Mississippi: a contingent rating approach. Forest Policy and Economics 15, 140-145.

Joshi, O., Mehmood, S.R., 2011. Factors affecting nonindustrial private forest landowners' willingness to supply woody biomass for bioenergy. Biomass and Bioenergy 35, 186-192.

Markowski-Lindsay, M., Stevens, T., Kittredge, D.B., Butler, B.J., Catanzaro, P., Damery, D., 2012. Family forest owner preferences for biomass harvesting in Massachusetts. Forest Policy and Economics 14, 127-135.

Mayfield, C.; C. Smith; B. Lattimore. 2007. Using the Adaptive Forest Management Planning Framework to Achieve Sustainable Bioenergy Production. In: Hubbard, W.; L. Biles; C. Mayfield; S. Ashton (Eds.). 2007. Sustainable Forestry for Bioenergy and Bio-based Products: Trainers Curriculum Notebook. Athens, GA: Southern Forest Research Partnership, Inc.

Monroe, M.C., Oxarart, A., 2011. Woody biomass outreach in the southern United States: A case study. biomass and bioenergy 35, 1465-1473.

Neary, D., 2002. Hydrologic values. Bioenergy from sustainable forestry: guiding principles and practice, 190-209. 
Paula, A.L., Bailey, C., Barlow, R.J., Morse, W., 2011. Landowner willingness to supply timber for biofuel: Results of an Alabama survey of family forest landowners. Southern Journal of Applied Forestry 35, 93-97.

Poudyal, N.C., Hodges, D.G., 2009. Factors influencing landowner interest in managing wildlife and avian habitat on private forestland. Human Dimensions of Wildlife 14, 240-250.

Proust, M.2013. Multivariate Methods. JMP statistical discovery manual. SAS.

Sample, V. A., Kittler, B., Refkin, D., \& Marsh, A. (2010). Forest sustainability in the development of wood bioenergy in the US.

Schaaf, K.A., and Broussard, S.R. 2006. Private forest policy tools: a national survey exploring the American public's perceptions and support. Forest Policy and Economics, 9(4): 316-334. doi:10.1016/j.forpol.2005.10.001.

Shivan, G. C., Mehmood, S. R. 2010. Factors influencing nonindustrial private forest landowners' policy preference for promoting bioenergy. Forest Policy and Economics 12, 581588.

Straka, Thomas J. 2011. Taxonomic review of classical and current literature on the perennial American family forest problem. Forests 2.3, 660-706.

Vance, E.D., Aust, W.M., Strahm, B.D., Froese, R.E., Harrison, R.B., Morris, L.A., 2014. Biomass harvesting and soil productivity: Is the science meeting our policy needs? Soil Science Society of America Journal 78, S95-S104.

Wolde, B., Lal, P., Alavalapati, J., Burli, P., Munsell, J., 2016a. Factors affecting forestland owners' allocation of non-forested land to pine plantation for bioenergy in Virginia. Biomass and Bioenergy 85, 69-75.

Wolde, B., Lal, P., Gan, J., Alavalapati, J., Taylor, E., Burli, P., 2016b. Determinants of enrollment in public incentive programs for forest management and their effect on future programs for woody bioenergy: evidence from Virginia and Texas. Canadian Journal of Forest Research 46, 775-782. 
Table 1. Percentage distribution of forestland owners by the different number of ways they can supply biomass for bioenergy production

\begin{tabular}{lc}
\hline Number of affirmative responses & Percentage of the respondents \\
\hline 0 (No to all options) & $16.29 \%$ \\
1 (Yes to only one option) & $25.0 \%$ \\
2 (Yes to two options) & $26.74 \%$ \\
3 (Yes to all three options) & $31.97 \%$
\end{tabular}

Table 2. Matrix showing the odds ratio that forestland owners willing to consider a given way of supplying biomass for bioenergy production will also consider another way of supplying biomass Response to woody bioenergy Odds ratio [95\% confidence interval]

$[\mathrm{A}] \quad[\mathrm{B}] \quad[\mathrm{C}]$

Supply biomass from existing stand

[A] 1

Allocate land for establishing

[B] 2.91 1 feedstock plantation $\left[\begin{array}{ll}1.4 & 6.08\end{array}\right]$

Change silviculture practice in response to woody bioenergy

[C]

8.77 [3.64 21.13]
5.74

[2.94 11.19]
1 
Table 3. Summary results for the final model

\begin{tabular}{|c|c|c|c|}
\hline Term & Estimate & $p$ value & $\begin{array}{l}\text { proportional } \\
\text { odds ratio }\end{array}$ \\
\hline Intercept $[0]$ & -0.88 & 0.0109 & \\
\hline Intercept[1] & 1.10 & 0.0017 & \\
\hline Intercept[2] & 2.85 & $<.0001$ & \\
\hline $\begin{array}{l}\text { Average diameter of tress on the largest tract }\{<14 \text { inches } \\
\text { Vs. }>14 \text { inches }\}\end{array}$ & -0.41 & 0.0132 & 0.66 \\
\hline $\begin{array}{l}\text { Heard about woody bioenergy before the survey [Yes Vs. } \\
\text { No] }\end{array}$ & -0.67 & 0.0002 & 0.51 \\
\hline $\begin{array}{l}\text { The importance of price offer in making supply decision } \\
\{2 \text { or less Vs } 3 \text { or more }\}\end{array}$ & 0.96 & $<.0001$ & 2.62 \\
\hline $\begin{array}{l}\text { The importance of improving scenic and wildlife habitat } \\
\text { and hunting opportunities }\{2 \text { or less Vs. 3or more }\}\end{array}$ & 0.49 & 0.0158 & 1.63 \\
\hline Age $\{<65$ Vs. $>65\}$ & -0.43 & 0.0148 & 0.65 \\
\hline Gross family income $\{<\$ 90,000 \mathrm{Vs}>\$ 90,000\}$ & 0.77 & 0.0053 & 2.16 \\
\hline $\begin{array}{l}\text { Gross family income }\{<22,000 \text { Vs. }>22,000 \text { to } \\
\$ 89,999 \$ 90,000\end{array}$ & 0.85 & 0.0721 & 2.35 \\
\hline $\begin{array}{l}\text { Proportion of income generated from working the land } \\
\{\text { None Vs. higher than } 0\}\end{array}$ & 0.26 & 0.1206 & 1.30 \\
\hline
\end{tabular}

Table 4. Associations between sustainability concerns of forestland owners and the number of ways they will simultaneously consider in supplying biomass for bioenergy production

\begin{tabular}{lllll}
\hline Sustainability concerns & $\begin{array}{l}\text { Gamma } \\
\text { measure of } \\
\text { association }\end{array}$ & $\begin{array}{l}\text { Std } \\
\text { Error }\end{array}$ & $\begin{array}{l}95 \% \text { confidence } \\
\text { interval }\end{array}$ \\
\hline $\begin{array}{l}\text { Harvesting forest biomass will affect wildlife } \\
\text { negatively }\end{array}$ & -0.17 & 0.090 & {$\left[\begin{array}{ll}-0.35 & 0.01\end{array}\right]$} \\
$\begin{array}{l}\text { Harvesting forest biomass affects soil and water } \\
\text { quality }\end{array}$ & -0.21 & 0.086 & {$\left[\begin{array}{ll}-0.38 & -0.04\end{array}\right]$} \\
$\begin{array}{l}\text { Harvesting forest biomass will require extra } \\
\text { employees and equipment }\end{array}$ & -0.13 & 0.089 & {$\left[\begin{array}{ll}-0.30 & 0.05\end{array}\right]$} \\
$\begin{array}{l}\text { Harvesting residual forest biomass affects the } \\
\text { standing timber growth and health negatively }\end{array}$ & -0.34 & 0.085 & {$\left[\begin{array}{ll}-0.51 & -0.18\end{array}\right]$} \\
$\begin{array}{l}\text { Not many landowners have harvested biomass for } \\
\text { biofuels production and ended up benefiting }\end{array}$ & -0.16 & 0.110 & {$\left[\begin{array}{lll}-0.37 & 0.06\end{array}\right]$} \\
$\begin{array}{l}\text { Development of forest biomass based bioenergy } \\
\text { will affect sustainable forest management efforts } \\
\text { negatively }\end{array}$ & -0.21 & 0.091 & {$\left[\begin{array}{lll}-0.39 & -0.03\end{array}\right]$} \\
$\begin{array}{l}\text { There are sufficient state guidelines and Best } \\
\text { Management Practices (BMPs) for harvesting }\end{array}$ & -0.03 & 0.107 & {$\left[\begin{array}{lll}-0.24 & 0.18\end{array}\right]$}
\end{tabular}


forest biomass

When harvesting biomass, soil and water quality $\quad 0.14 \quad 0.096 \quad\left[\begin{array}{lll}-0.05 & 0.33\end{array}\right]$ can be maintained by implementing forest BMPs

Table 5. Cochran Armitage trend test for the relationship between the number of ways forestland owners will consider simultaneously supply and their forest management plans

\begin{tabular}{lcc}
\hline Basis of comparison & Z statistics & P value \\
\hline Clear-cutting & 2.13 & 0.033 \\
Partial cutting & 2.96 & 0.003 \\
Harvest fuel wood for sale or own use & 1.54 & 0.123 \\
Remove invasive plant species & 0.15 & 0.881 \\
Harvest/supply wood for saw log or veneer & 1.64 & 0.101 \\
Harvest/supply wood for pulp/paper mills & 3.59 & 0.000 \\
Harvest/supply wood for chip-n-saw mills & 2.86 & 0.004 \\
Build or maintain roads & 0.74 & 0.460 \\
Develop a written forest management plan for the woodland & 3.41 & 0.001
\end{tabular}

